\title{
Cannabis Use and Sleep Quality in Daily Life: a Daily Diary Study of Adults Starting Cannabis for Health Concerns
}

\author{
Brenden Tervo-Clemmens ${ }^{1}$, William Schmitt ${ }^{1}$, Grace Wheeler ${ }^{1}$, Megan Cooke ${ }^{1}$, \\ Randi M. Schuster ${ }^{1}$, Sarah Hickey ${ }^{1}$, Gladys Pachas ${ }^{1}$, A. Eden Evins ${ }^{1}$, Jodi Gilman ${ }^{1}$ \\ ${ }^{1}$ Center for Addiction Medicine, Department of Psychiatry, Massachusetts General Hospital and \\ Harvard Medical School, Boston, MA
}

\begin{abstract}
Background: Legalization of cannabis for medical uses has proceeded without well-controlled studies. Real world patterns of medical cannabis use are highly variable and rarely overseen by a physician. Smartphone assessments that capture ecologically valid patterns of medical cannabis use and health symptoms may help clarify risks and benefits.
\end{abstract}

Methods: As part of a larger, randomized trial (NCT03224468), adults ( $\mathrm{N}=181)$ seeking cannabis for insomnia, pain, or anxiety or depressive symptoms were randomized to obtain a medical cannabis card immediately (MCC) or to a waitlist control (WLC) and completed 12weeks of daily web-based surveys on cannabis use and three health outcomes: sleep, pain, and depressive symptoms.

Results: Completion rates in this long-term, daily survey design were high (median completed assessments: 72 out of 90 days). Daily reports of cannabis use were consistent with monthly interview assessments and urinalysis. The MCC group increased cannabis use frequency following randomization, while WLC did not. Within the MCC group, self-reported sleep quality was significantly higher on cannabis use days, compared to nonuse days. The MCC group displayed long-term sleep improvements, paralleled by increased cannabis frequency. Daily associations between cannabis use and self-reported pain or depressive symptoms were not significant.

Conclusion: Cannabis use is associated with same day improvements in self-reported sleep quality, but not pain or depressive symptoms, although sleep improvements occurred within the context of potentially risky increases in use. Long-term, web-based assessments of cannabis appear valid and feasible, providing a robust method for future real-world effectiveness studies with expanded and objective measures.

Funding/Support: This work was funded by R01DA042043; PI: JMG.

Word Count Main Text: 5,760 
medRxiv preprint doi: https://doi.org/10.1101/2022.01.19.22269565; this version posted January 22, 2022. The copyright holder for this preprint (which was not certified by peer review) is the author/funder, who has granted medRxiv a license to display the preprint in perpetuity.

All rights reserved. No reuse allowed without permission.

\section{Introduction}

Access to cannabis is rapidly increasing in the United States as a growing number of states legalize medical and recreational cannabis (Goodman et al., 2020). Though patients increasingly seek clinician input on the use of medical cannabis to address chronic mental and physical health challenges, including with sleep, mood, and pain (Sarris et al., 2020)(Lintzeris et al., 2018), the efficacy of medical cannabis is inconclusive (Abrams, 2018)(Sarris et al., 2020). Recent systematic reviews suggest that relatively stronger evidence exists for medical cannabis improving sleep quality, relative to improvements in mood symptoms (e.g., anxiety and depression) or reducing chronic pain (Abrams, 2018)(Sarris et al., 2020)(Analgesia, 2021). Nevertheless, mixed evidence exists within each symptom domain and few studies have evaluated the effects of cannabis on multiple domains in the same study.

In the United States, the complex legal status of cannabis (federally prohibited but with individual state-level laws (Boehnke et al., 2019) (Mead, 2017)(Goodman et al., 2020) (Pacula et al., 2014)) and lack of federal oversight (i.e., Food and Drug Administration: FDA) and evaluation of dosage, safety, and efficacy (fda.gov) pose a challenge in determining potential therapeutic effects of cannabis. In routine practice, many, if not most, medical cannabis patients use cannabis without ongoing physician supervision (Sexton et al., 2016), lack clear guidelines for dosing (see (MacCallum and Russo, 2018)), and have the flexibility to purchase a wide range of cannabis products (Hazekamp et al., 2013) (Cranford et al., 2016) of potentially unclear or mislabeled chemical composition (Vandrey et al., 2015)(Gilman et al., 2021b). Real-world patterns of medical cannabis use are thus highly variable, patient specific, and may be influenced by familiarity and/or expectations for use that facilitate navigation of its complex legal status. 
medRxiv preprint doi: https://doi.org/10.1101/2022.01.19.22269565; this version posted January 22, 2022. The copyright holder for this preprint (which was not certified by peer review) is the author/funder, who has granted medRxiv a license to display the preprint in perpetuity.

All rights reserved. No reuse allowed without permission.

Pragmatic clinical trials, that for example randomize individuals to receive access to medical cannabis or to a waitlist control (Gilman et al., invited to resubmit, (Gilman et al., 2021a)) provide an opportunity to characterize the potential therapeutic effectiveness of cannabis under real-world conditions. Experience sampling studies (Csikszentmihalyi and Larson, 2014)(Kahneman et al., 2004) that capture patient-specific, in-the moment (ecological momentary assessment) or on the same day (daily diary) patterns of cannabis use (Verdoux et al., 2003) and physical and mental health symptoms through intensive longitudinal tracking via web-based devices (e.g., smartphones) can provide essential complementary data for these pragmatic medical cannabis studies. Owing to the complex legal status of medical cannabis and the relatively novel methodological requirements of intensive longitudinal assessment, however, limited work has used experience sampling designs (e.g., daily diary, ecological momentary assessment) in studies of medical cannabis. This is particularly true across the relatively longer time scales used in pragmatic, effectiveness studies amenable to medical cannabis (e.g., 12 weeks) compared to the shorter timescales most frequently used in experience sampling and naturalistic studies of cannabis (<1 month)(Goodhines et al., 2019)(Verdoux et al., 2003)(Buckner et al., 2012))(Schuster et al., 2016)(Budney et al., 2001). Further, few studies have validated intensive web-based cannabis self-report from experience sampling studies against field-standard interview-based assessments or urinalysis. As such, despite the alignment of experience sampling design to studies of medical cannabis, the feasibility and validity of this method remains unknown.

As part of a larger pragmatic clinical trial that randomized patients interested in medical cannabis to a medical cannabis card or waitlist control (Gilman et al., invited to resubmit, (Gilman et al., 2021a)), the current project reports exploratory analyses from a novel intensive 
medRxiv preprint doi: https://doi.org/10.1101/2022.01.19.22269565; this version posted January 22, 2022. The copyright holder for this preprint (which was not certified by peer review) is the author/funder, who has granted medRxiv a license to display the preprint in perpetuity.

All rights reserved. No reuse allowed without permission.

longitudinal, daily diary design. Participants provided daily web-based, self-reports of medical cannabis use and symptoms of sleep, mood, and pain for the first 90 days of receiving access to a medical cannabis card or placement on the waitlist. To our knowledge, this is the first intensive longitudinal, experience sampling study (ecological momentary assessment or daily diary) of new medical cannabis use and the first long-term ( $>1$ month) experience sampling study of cannabis use. The primary aims for this study were to 1) determine the feasibility and validity of intensive longitudinal assessment of cannabis use in adults starting cannabis use for health concerns and 2) examine the association between cannabis use and reported symptoms of sleep, mood, and pain across the multiple timescales afforded by the long-term, daily diary design (e.g., short-term same day effects, long-term change over several months).

\section{Method}

\section{Participants}

Participants were part of a single site clinical trial (NCT03224468; Gilman et al., invited to resubmit, (Gilman et al., 2021a)) that randomized participants to either obtain a medical cannabis card (MCC) in the community at the time of randomization or to wait 12 weeks before obtaining a medical cannabis card (waitlist control (WLC)). Participants were adults (18-65years-old) with self-reported symptoms of insomnia, pain, or anxiety and/or depression ("mood"), were generally healthy, with no known, unstable major medical condition, who expressed an interest in obtaining a medical cannabis card but did not yet possess one, reported less than daily current cannabis use, and did not meet criteria for a cannabis use disorder.

Our initial sample consisted of the 186 participants randomized to MCC or WLC who participated in monthly assessments (Gilman et al., invited to resubmit, (Gilman et al., 2021a)). The final analytic sample (see below) for this study consisted of 181 of these participants. 
medRxiv preprint doi: https://doi.org/10.1101/2022.01.19.22269565; this version posted January 22, 2022. The copyright holder for this preprint (which was not certified by peer review) is the author/funder, who has granted medRxiv a license to display the preprint in perpetuity.

All rights reserved. No reuse allowed without permission.

Participant demographics and baseline characteristics are presented in Table 1. See Gilman et al., invited to resubmit, (Gilman et al., 2021a) for study design, participant characteristics, and randomization. Study procedures were approved by Partners Human Research Committee.

Participants provided informed consent and were financially compensated for participation.

Table 1. Stratification and Demographic and Baseline Assessments from Analysis Sample

MCC WLC

\begin{tabular}{lcc}
\hline Demographics & & \\
N Participants & 102 & 79 \\
Presenting Problem & & \\
$\quad$ (N Affective $\mid$ Sleep | Pain) & $44|22| 36$ & $37|19| 23$ \\
N Female | Male | Non-Binary & $68|33| 1$ & $50|29| 0$ \\
Age in years & $38.26(14.31)$ & $36.69(14.56)$ \\
$\quad$ Education years & $16.71(2.31)$ & $16.27(2.74)$ \\
Baseline Assessments & & \\
$\quad$ Cannabis Uses Per-Day & $0.50(0.63)$ & $0.58(0.61)$ \\
Athens Insomnia Scale Total & $9.71(4.95)$ & $9.63(4.40)$ \\
HADS-Anxiety Total & $7.50(4.35)$ & $7.91(4.34)$ \\
HADS-Depression Total & $5.01(3.51)$ & $5.04(4.05)$ \\
Brief Pain Inventory Worst Pain & $5.12(2.30)$ & $5.52(2.20)$ \\
\hline
\end{tabular}

Note. No significant differences ( $\mathrm{p}$ 's $>.243$ ) were found between groups on demographic measures or baseline assessments. Number in parentheses following quantitative variables in standard deviation. HADS, Hospital Anxiety and Depression Scale. See document for measure citations.

\section{Procedures}

Following a screening visit to assess basic study eligibility, participants were randomized, stratified by sex, age, and presenting problem for which they were seeking medical cannabis (self-reported problems with sleep, pain or mood [anxiety or depression]) to either the MCC group, in which they were to obtain a medical cannabis card without delay, or to the WLC group, in which they agreed to wait 12 -weeks before obtaining a medical cannabis card. Study staff did not provide medical cannabis cards or cannabis products. Rather, participants 
medRxiv preprint doi: https://doi.org/10.1101/2022.01.19.22269565; this version posted January 22, 2022. The copyright holder for this preprint (which was not certified by peer review) is the author/funder, who has granted medRxiv a license to display the preprint in perpetuity.

All rights reserved. No reuse allowed without permission.

randomized to the MCC group were instructed that they could obtain a medical cannabis card in the community without delay to participate in the study, and in detailed subsequent analyses, we determined changes in their cannabis usage via biochemically verified assessments. Owing to the expected dropout from the MCC group due to financial and logistic challenges inherent in obtaining a medical cannabis card, participants were randomized 2:1 MCC: WLC. Following randomization, participants completed an experimenter administered baseline visit where primary study variables, including cannabis use, sleep, anxiety and depression, and pain were assessed, and they received instructions on subsequent web-based assessments and daily selfreports. For the MCC group, the baseline visit was scheduled to be as close as possible to the receipt date of the medical cannabis card; if participants received the card prior to the baseline visit, they were instructed to not begin using their medical cannabis card until after the baseline visit (on average, MCC participants received their cards four days before the baseline visit; see Results for more discussion). Following the randomization and baseline assessment, participants were prospectively followed for the 12-week, randomized study period using 1) in-person or virtual experimenter administered visits (all experimenter administered visits became virtual in March 2020 due to COVID-19 pandemic) at 2-, 4-, and 12-weeks following randomization and 2) using daily web-based assessments of self-reported cannabis use, sleep, pain, depression. The current project reports the novel results of the daily web-based assessments.

\section{Measures}

Baseline Substance Use, Psychiatric, Medical Symptoms. Symptoms of cannabis use disorder (CUD), a study exclusion criterion, were assessed by the CUD Checklist for DSM-5 (American Psychiatric Association, 2013). Baseline and monthly cannabis use frequency was assessed at each experimenter administered study visit via an interview with research staff where 
medRxiv preprint doi: https://doi.org/10.1101/2022.01.19.22269565; this version posted January 22, 2022. The copyright holder for this preprint (which was not certified by peer review) is the author/funder, who has granted medRxiv a license to display the preprint in perpetuity.

All rights reserved. No reuse allowed without permission.

participants reported their cannabis use according to the following options: "Once or more per day”, “5-6 days a week”, “3-4 days a week”, “1-2 days a week”, ”Less than once a week”, "Less than once every two weeks". Baseline sleep, anxiety, depression, and pain symptoms were assessed via the Athens Insomnia Scale (Soldatos et al., 2000), Hospital Anxiety and Depression Scale (Snaith, 2003), and Brief Pain Inventory (Tan et al., 2004), respectively.

Daily Self-Reports. Participants provided daily reports on cannabis use and sleep, pain and depression symptoms via a secure web-based application, designed for this study, that was available via smartphone and computer. Participants used their own devices to complete the surveys. Participants were instructed to complete assessments at the same time every day; questions were based on the previous 24 hours. For cannabis use, participants first reported whether they had used cannabis ("Did you use Medical Marijuana Today": "Yes" versus" No") and if they had used cannabis that day, to report an approximation of the number of cannabis use occasions ("Please indicate the time(s) you used Medical Marijuana"; participants selected each hour of the day that they used cannabis [e.g., "6:00pm","7:00pm", "8:00pm”, ...], although hours were used as a memory aid and to provide a standard metric of occasion, but specific times were not saved.) Within this application, participants also provided daily reports, from 1 (low) to 10 (high) using sliders, on pain ("How much pain did you feel today on average": “(1) No pain”, “(10) Extreme pain” ), sleep (“How was your sleep quality last night”: “(1)Very poor”, “(10) Very good”). and depression (“How depressed did you feel today: “(1) Not at all”, “(10) Extremely").

Urinalysis. At experimenter administered visits, whether in person or virtual, urine was collected for assessment of cannabinoids and their metabolites. Urine was collected in person for clinic-based visits and by mail for virtual visits. Concentration of $\mathrm{THC}, \mathrm{CBD}$, their primary 
medRxiv preprint doi: https://doi.org/10.1101/2022.01.19.22269565; this version posted January 22, 2022. The copyright holder for this preprint (which was not certified by peer review) is the author/funder, who has granted medRxiv a license to display the preprint in perpetuity.

All rights reserved. No reuse allowed without permission.

metabolites, and 15 other cannabinoids in urine was assessed via high performance liquid chromatography with tandem mass spectrometry (see Supplemental S1 and (Gilman et al., 2021b) for more discussion).

Adverse Events. Adverse events are documented in the primary report from this trial (Gilman et al., invited to resubmit, (Gilman et al., 2021a)). No participants were withdrawn from the study due to an adverse event.

\section{Analysis}

Feasibility and Validation of Daily Cannabis Reports. Feasibility analyses used descriptive statistics and per-participant and group-level data visualization to characterize the number of completed daily surveys. Validity analyses utilized linear regression to compare cannabis use reported in the daily diary design to cannabis use reported in field-standard, interview-based assessments, and cannabinoid metabolites from urinalysis.

\section{Daily Diary Associations between Cannabis use and Physical and Mental Health}

Symptoms. Linear mixed effects models were used to examine associations between cannabis use and sleep, pain, and anxiety and depression symptoms across the 12-week daily diary period. Cannabis use and the effect of cannabis use on symptoms was examined at the within-person, day-level by comparing days with versus without reported cannabis use. To ensure our results reflected these within-person, same day effects, we covaried for between-person differences in the total number of cannabis use days. All models also included fixed and random effects (see below) of days since baseline to 1) account for person-specific changes in symptoms following randomization to $\mathrm{MCC}$, when examining day-level effects and 2) to examine long-term changes in symptom expression following randomization. Random effects within mixed models, estimated for each participant, were an intercept, and slope effects for days since the baseline 
medRxiv preprint doi: https://doi.org/10.1101/2022.01.19.22269565; this version posted January 22, 2022. The copyright holder for this preprint (which was not certified by peer review) is the author/funder, who has granted medRxiv a license to display the preprint in perpetuity.

All rights reserved. No reuse allowed without permission.

visit, the difference between use and nonuse days, and the interaction between days since randomization and use versus nonuse days. Per-participant autocorrelated (order 1) error structures, with respect to days since baseline, were also modeled. As a central focus of the project was on potential symptom relief from medical cannabis, analyses focused on same-day (i.e., zero lag) associations between cannabis use and health symptoms. For sleep quality, this meant the daily sleep measure ("How was your sleep quality last night") was shifted forward one day ("lead") with respect to the cannabis use metric, to model the effect of cannabis use on sameday (in the case of sleep, same-night) symptoms for all three outcomes.

Models were run with the three symptoms separately (sleep, pain, or depression) as dependent variables and cannabis use measures (use versus nonuse day, number of use occasions) as the independent variable. This model included age, years of education (see results for justification), and presenting problem (stratification variable: self-reported challenges with sleep, pain or mood) as covariates. In addition to the main effects, secondary analyses examined the associations between same day cannabis use and health symptoms in subgroups according to participant's self-reported presenting problem that was used in stratification for randomization (see Procedure). Statistical inference was based on both effect size (e.g., differences in standard deviation units) and significance values (Cumming, 2014).

Probability of Cannabis Use Following Randomization. In order to better understand any potential longer-term changes in health symptoms following randomization, cannabis use frequency (use day versus nonuse day) was modeled as a dependent variable as a function of time since baseline, via generalized linear mixed effects models with a logit link function. Fixed effects again included participant age, years of education, and presenting problem as covariates. Random intercepts and a slope for days since baseline were included for each participant. 
medRxiv preprint doi: https://doi.org/10.1101/2022.01.19.22269565; this version posted January 22, 2022. The copyright holder for this preprint (which was not certified by peer review) is the author/funder, who has granted medRxiv a license to display the preprint in perpetuity.

All rights reserved. No reuse allowed without permission.

Sensitivity Analysis. Sensitivity analyses was performed restricting the analyses to only those MCC participants who had cannabinoid metabolites detected via urinalysis during at least one timepoint of the study period. Unless otherwise stated, the magnitude (effect size) and pattern of significance of primary results were unchanged from those presented in the main document (See Supplemental S2).

\section{Results}

Participant Inclusion. Owing to delays in receiving a medical cannabis card, two participants from the MCC group completed the majority ( $>45$ / 90 days) of their daily diary assessments prior to receiving the MCC card and were excluded from primary analyses. Additionally, to balance result generalizability, which may be undermined by strict thresholds for participant inclusion (Ji et al., 2018), and the complexity of missing data and model stability, we used a liberal criterion for completion rate of daily assessments for inclusion in our primary analyses. As a result, only three participants who did not have at least 9 out of $90(10 \%)$ days with completed assessments were excluded from primary analyses. Therefore, our final primary analytic sample was 181 participants. Daily diary assessment completion rates were not significantly associated with primary study variables and are presented with $(\mathrm{N}=186)$ and without $(\mathrm{N}=181)$ excluded participants (see below).

Daily Diary Completion Rates. Completion rates of daily surveys were high overall and consistent with prior ambulatory assessment studies of cannabis use in clinical samples with shorter study periods (e.g., less than 30 days (Goodhines et al., 2019)(Verdoux et al., 2003)(Buckner et al., 2012) see discussion). Among the full sample ( $\mathrm{N}=186$; no analysis-specific exclusions, see above), the median number of days with completed surveys was 72 out of 90 days, with a mean of $66.21(\mathrm{SD}=20.02)$ and range of 1-90 (Figure $1 \mathrm{~A})$. In the final analytic 
medRxiv preprint doi: https://doi.org/10.1101/2022.01.19.22269565; this version posted January 22, 2022. The copyright holder for this preprint (which was not certified by peer review) is the author/funder, who has granted medRxiv a license to display the preprint in perpetuity.

All rights reserved. No reuse allowed without permission.

sample $(\mathrm{N}=181)$, the median number of days with completed surveys was 72 out of 90 days, with a mean of $67.00(\mathrm{SD}=18.68)$ and range of 12-90 (Figure 1A). Completion rates remained high throughout the entirety of the 90-day study period (see Supplemental S3).

A. Daily Diary Completion Rates

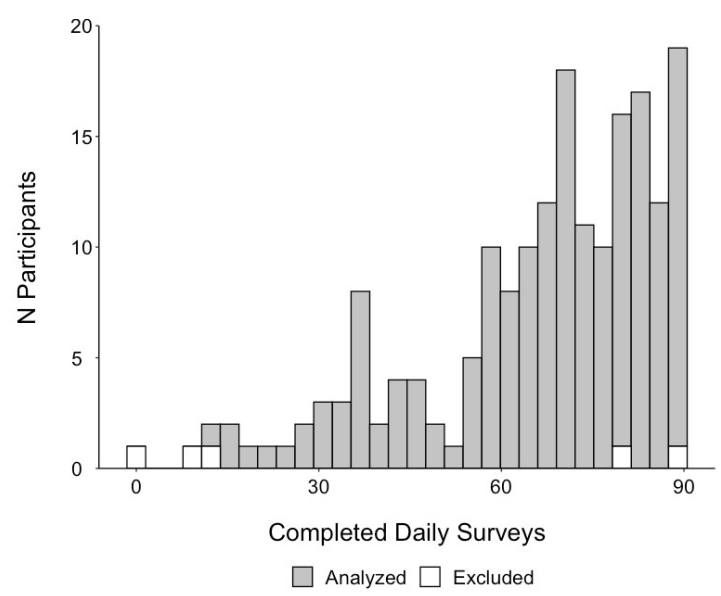

B. Percent of Daily Diaries with Cannabis Use

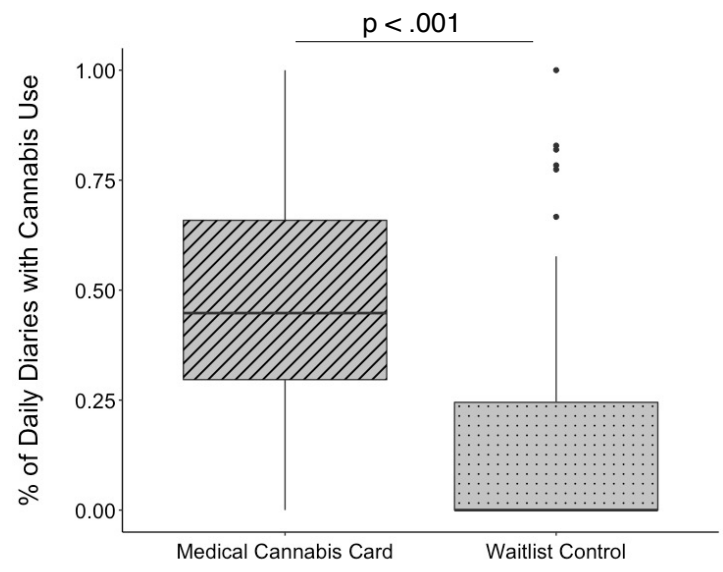

Figure 1. Daily Cannabis Diary Completion. A) Histogram displaying the number of completed diaries for each participant. White bars indicate the five excluded participants; grey bars indicate the 181 participants in the final analytic sample (see Methods). B) Boxplots displaying the percent of completed daily surveys where participants indicated they had used cannabis in the medical cannabis card (MCC) group compared to the waitlist control (WLC) group.

Among the full sample $(\mathrm{N}=183)$, the total number of completed surveys did not significantly differ between MCC (mean=68.45 days) and WLC (mean=63.31 days) groups $(\mathrm{t}=1.68, \mathrm{p}=.095)$, nor as a function of presenting problem used for stratification in randomization (self-reported challenges with sleep, pain or mood; $\mathrm{F}=0.96, \mathrm{p}=.386$ ), and was likewise not related to baseline sleep $(r=.005, \mathrm{p}=.943)$, pain $(\mathrm{r}=.140, \mathrm{p}=.186)$, depression $(\mathrm{r}=-.046, \mathrm{p}$ $=.529)$, or anxiety $(\mathrm{r}=-.103, \mathrm{p}=.160)$ measures. The number of completed surveys did not significantly differ between men and women $(t=0.98, p=.327)$. There were significant associations between the number of completed surveys and participant age $(r=.237, p=.001)$, where older participants completed more surveys, and completed surveys and years of education, where those with more years of education completed more surveys $(r=.175, p=.017)$. Age and 
medRxiv preprint doi: https://doi.org/10.1101/2022.01.19.22269565; this version posted January 22, 2022. The copyright holder for this preprint (which was not certified by peer review) is the author/funder, who has granted medRxiv a license to display the preprint in perpetuity.

All rights reserved. No reuse allowed without permission.

years of education were used as covariates in all subsequent analyses. The pattern of significant associations between completion rates of daily surveys and study variables was unchanged when restricting analyses to only the participants in the primary analytic sample $(\mathrm{N}=181$; see Methods for inclusion criteria).

\section{Medical Cannabis Card Group Reports More Cannabis Use Days than Waitlist}

Control. Daily diary data confirm randomization to a medical cannabis card (MCC) is associated with more frequent subsequent cannabis use; the MCC group had a significantly higher percentage of daily reports that included cannabis use, compared to the WLC (MCC: $48.2 \%$ vs WLC: $15.4 \%, \mathrm{p}<.001)($ Figure 1B). Daily diary data likewise indicated a significant increase in cannabis frequency as a function of time since the baseline visit in the MCC group $(\mathrm{p}=.007)$, but not the WLC group ( $\mathrm{p}=.071)$ (see below).

\section{Validating Daily Diary with Field-Standard Interview Assessments and Urinalysis.}

To validate cannabis use data collected via web-based, daily diaries, we compared the MCC group's (n=101 [1 MCC participant did not have 1 month follow-up data]) cannabis use frequency from this method (percentage of daily surveys reporting cannabis use) with 1) cannabis frequency identified in a field-standard, in person interview-based assessment (see Methods) querying the first month of the daily diary period and 2) the presence of cannabinoid metabolites in urine after the first month of the daily diary period (i.e., urinalysis from experimenter-administered, two-week or one-month visits). The first month of data were used in these analyses given the potential lingering effects of cannabinoid metabolites in urine following use, and to avoid "carry-over" effects where qualitatively positive urinalysis results from the first month might influence subsequent results (cf., (Schuster et al., 2020). Qualitative results (detected versus non-detected) were used given the high degree of individual variability in 
medRxiv preprint doi: https://doi.org/10.1101/2022.01.19.22269565; this version posted January 22, 2022. The copyright holder for this preprint (which was not certified by peer review) is the author/funder, who has granted medRxiv a license to display the preprint in perpetuity.

All rights reserved. No reuse allowed without permission.

metabolite detection from urinalysis that is dependent on person-specific and methodological factors ((Goodwin et al., 2008)(Gilman et al., 2021b) see Supplemental S1 for additional discussion).

A. Daily Diary versus Interview-Based Cannabis Assessment

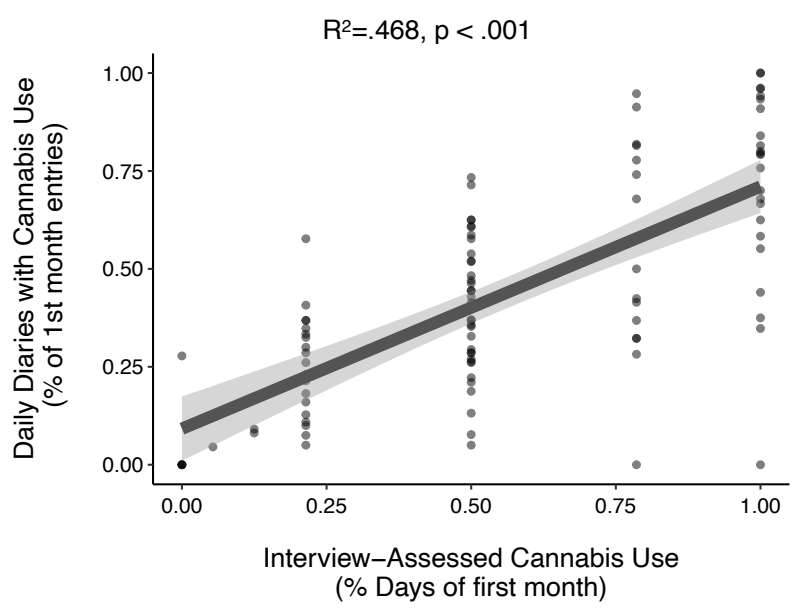

B. Daily Diary versus Cannabinoid Metabolites

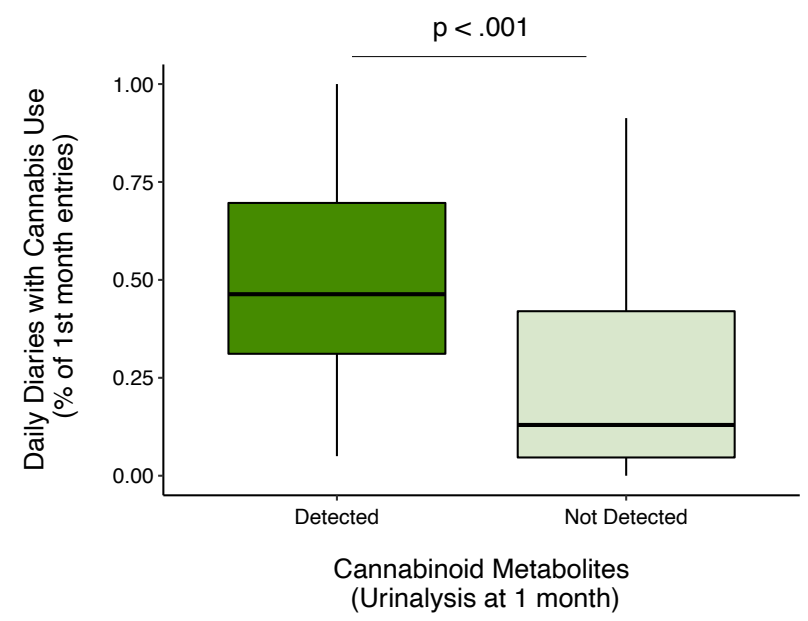

Figure 2. Daily Cannabis Diary Validation. A) Association between per-participant past month cannabis use frequency assessed via daily diary (y-axis) and via experimenter interview (x-axis) among those participants in the medical cannabis card (MCC, $\mathrm{n}=101$ ) group. B) Per-participant past month cannabis use frequency derived via daily diary for those participants in the MCC with and without cannabinoid metabolites detected in their urine.

Cannabis use frequency collected via daily diaries (percentage of daily surveys with cannabis use) over the first month of the study was robustly associated with retrospective past month cannabis use frequency (number of days used) determined via structured interview questions with study staff at the experimenter-administered, four-week visit (standardized regression coefficient: $\beta=.685, \mathrm{p}<.001$, partial $\mathrm{R}^{2}=.468$ while covarying participant age and years of education) (Figure 2A). Cannabis use frequency collected via daily diaries also disambiguated those in the MCC group with any cannabinoid metabolites (see Supplemental S1 for complete metabolite list) in their urine compared to those without detectable cannabinoids in their urine at either the two week or one month experimenter administered (cannabinoid 
medRxiv preprint doi: https://doi.org/10.1101/2022.01.19.22269565; this version posted January 22, 2022. The copyright holder for this preprint (which was not certified by peer review) is the author/funder, who has granted medRxiv a license to display the preprint in perpetuity.

All rights reserved. No reuse allowed without permission.

metabolite detected after first month [n=75]: median diaries with use $=46.3 \%$, cannabinoid metabolites not detected after first month $[\mathrm{n}=26]$ : median diaries with use $=13.0 \%, \mathrm{p}<$ .001)(Figure 2B) as well as specifically those with THC metabolites (THC metabolite detected after first month [n=70]: $46.7 \%$ diaries with use, THC metabolites not detected after first month $[\mathrm{n}=31]: 21.4 \%$ diaries with use, $\mathrm{p}<.001$ ). See Supplemental S1 and (Gilman et al., 2021b) for extended detail on urinalysis scoring procedures.

\section{Same Day Associations between Medical Cannabis Use and Health Symptoms in the}

MCC Group. Having established the feasibility and validity of the web-based daily cannabis assessments, we next examined within-person associations between cannabis use and health symptoms across the full 90-day monitoring period. Among the full MCC group $(\mathrm{N}=102)$, better sleep quality was reported for the night following cannabis use days compared to nonuse days (difference in standard deviation units: $\Delta \mathrm{z}=.115, \mathrm{p}<.001$ )(Figure 3A). As our primary analyses utilized within-person day-level cannabis use and health symptom information and covaried for between-person associations between cannabis frequency and sleep (as well as salient demographic variables: see Methods), this result is consistent with medical cannabis use being associated with small, but significant same day improvements in self-reported sleep quality. The effect of same-day cannabis use on sleep quality significantly varied (omnibus test statistic for interaction from mixed model: $\chi 2=7.32, \mathrm{p}=.026$ ) as a function of participants' presenting problem at baseline (self-reported challenges with sleep, pain or mood), with post-hoc testing demonstrating significant, same day improvements of sleep on cannabis use days, compared to nonuse days for participants who entered the study based on self-reported problems with sleep $(\Delta \mathrm{z}=.178, \mathrm{p}=.007)$ and $\operatorname{mood}(\Delta \mathrm{z}=.178, \mathrm{p}<.001)$ but not pain $(\Delta \mathrm{z}=.022, \mathrm{p}=$ .623)(Figure 3A). The effect sizes and statistical significance of associations between cannabis 
medRxiv preprint doi: https://doi.org/10.1101/2022.01.19.22269565; this version posted January 22, 2022. The copyright holder for this preprint (which was not certified by peer review) is the author/funder, who has granted medRxiv a license to display the preprint in perpetuity.

All rights reserved. No reuse allowed without permission.

use days vs. nonuse days with sleep quality did not change when restricting the MCC sample to

A.

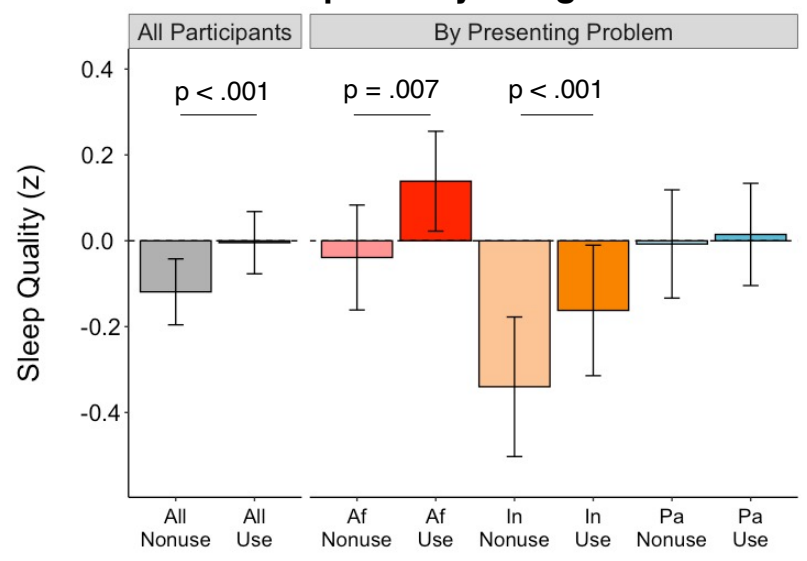

B.

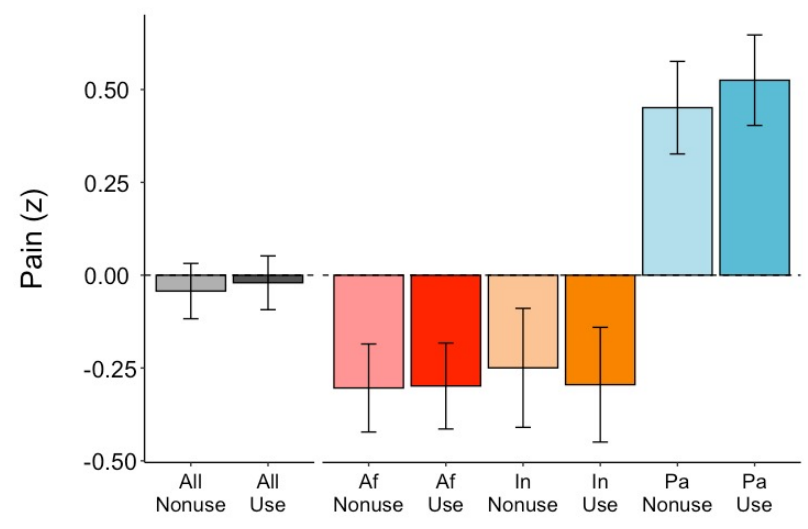

C.

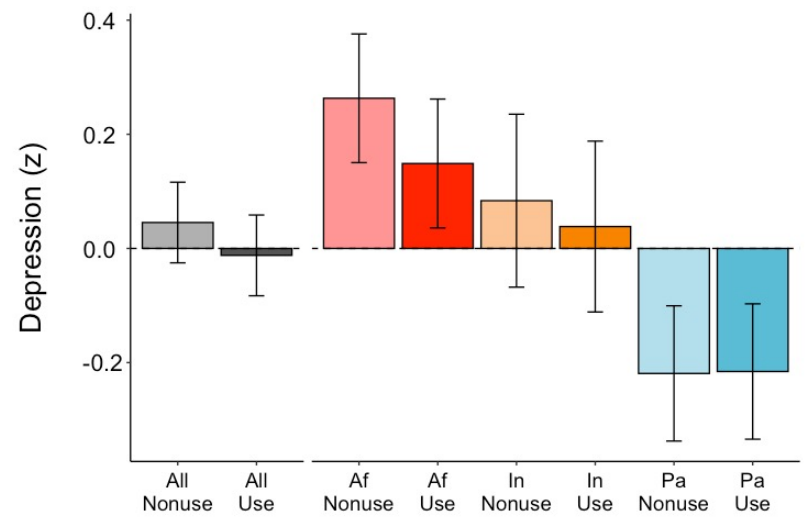

only those with cannabinoid metabolites detected via urinalysis (Supplemental S2). Cannabis use days and nonuse days did not statistically differ in self-reported pain $(\Delta \mathrm{z}=.023, \mathrm{p}=$ .428)(Figure 3B) and interactions between presenting problem (self-reported challenges sleep, pain, or mood) and cannabis use vs. nonuse days were not significant with respect to pain symptoms $(\chi 2=2.44, \mathrm{p}=.295)$. There was a very small, but statistically significant difference between cannabis use days and nonuse days in the full MCC sample $(\Delta \mathrm{z}=$ $.058, \mathrm{p}=.026)$, suggestive of use days being associated with slightly lower depressive symptoms compared to nonuse days; Figure 3C). This effect however was not significant in supplemental analyses (S2) that restricted the sample to those with cannabinoid metabolites detected via urinalysis $(\Delta \mathrm{z}=-.038$, $\mathrm{p}=$.197). The interaction between presenting Presenting Problem: All Participants 
medRxiv preprint doi: https://doi.org/10.1101/2022.01.19.22269565; this version posted January 22, 2022. The copyright holder for this preprint (which was not certified by peer review) is the author/funder, who has granted medRxiv a license to display the preprint in perpetuity.

All rights reserved. No reuse allowed without permission.

significant with respect to depressive symptoms in the full MCC sample $(\chi 2=4.32, \mathrm{p}=.115)$ or

in those with cannabinoid metabolites detected via urinalysis $(\chi 2=2.37, \mathrm{p}=.306)$.

Figure 3. Differences in Health Symptoms between Cannabis Use Days and Nonuse Days in the Medical Cannabis Card Group. Differences in self-reported same night sleep quality (A), same day pain (B), and same day depression symptoms (C) in cannabis use days (darker colors) and nonuse days (lighter colors) in the medical cannabis card (MCC) group. Values shown for all MCC participants $(\mathrm{N}=102$; grey) and those whose presenting problem was mood (depression or anxiety symptoms, Af: $n=44$, red), challenges with sleep ( $\mathrm{n}$ : $\mathrm{n}=22$, orange), or pain $(\mathrm{Pa}: \mathrm{n}=36$, blue). Displayed values are estimated marginal means and their standard errors from linear mixed effects models fit in primary analyses (covariates include per-participant estimates of age, years of education, and the proportion of daily diary days that included cannabis use [i.e., between-person effect]); see Methods for more detail on parameterization).

\section{Linking Daily and Long-Term Sleep Self-Reported Sleep Quality Changes}

Associated with New Medical Cannabis Use. Having demonstrated that compared to nonuse days, cannabis use days were associated with small to moderate statistically significant improvements in self-reported sleep quality including in analyses leveraging repeated urinalysis to confirm cannabis reports, we next sought to determine how these same day sleep improvements may manifest in long-term changes in sleep across the duration of the daily diary period. We found that across the daily diary period (90 days), the MCC group displayed significant aggregate increases in self-reported sleep quality following randomization (per-day standardized association ( $\mathrm{z}$ units): $\beta=.002, \mathrm{p}=.007$; total sleep change across 90 days ( $\mathrm{z}$ units): .195 ), while the WLC group did not (per-day standardized association ( $\mathrm{z}$ units): $\beta=-.0003$, $\mathrm{p}=.652$; total sleep change across 90 days ( $\mathrm{z}$ units): .030) (Figure 4A). This effect was driven by those in the MCC group with a presenting problem of insomnia, whose sleep quality significantly increased over time (per-day standardized association ( $\mathrm{z}$ units): $\beta=.006, \mathrm{p}<.001$; total sleep change across 90 days ( $\mathrm{z}$ units): .675) and was significantly different $(\chi 2=11.45, \mathrm{p}$ $=.003$ ) than MCC participants with a presenting problem of pain or mood (Figure 4A). The pattern of longer-term increases in sleep quality across the daily diary period among those with a 
medRxiv preprint doi: https://doi.org/10.1101/2022.01.19.22269565; this version posted January 22, 2022. The copyright holder for this preprint (which was not certified by peer review) is the author/funder, who has granted medRxiv a license to display the preprint in perpetuity.

All rights reserved. No reuse allowed without permission.

presenting problem of insomnia was mirrored in being the only MCC subgroup with a significant increase (per-day odds ratio: 1.02, $\mathrm{p}<.001$; probability of a cannabis use day on study day 1 :

.370 , probability of use day on study day $90: .832$ ) in the frequency of cannabis use days

following randomization (Figure 4B). This suggested that long-term improvements in sleep-

quality were likely driven by an increase in cannabis use frequency, rather than for example, the

lasting effect of a single cannabis use.

A.

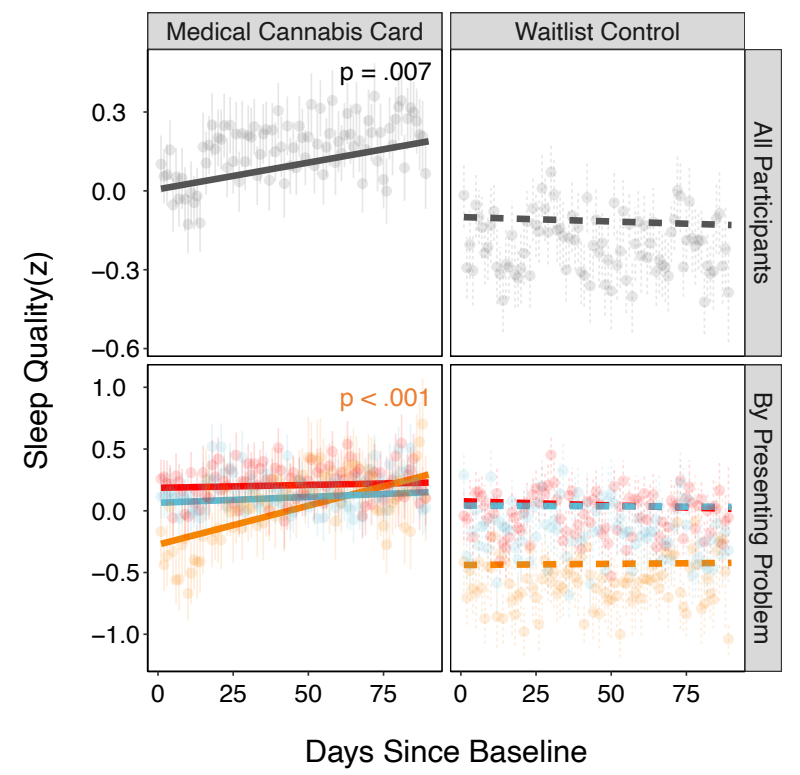

B. Probability of Cannabis Use

Following Randomization

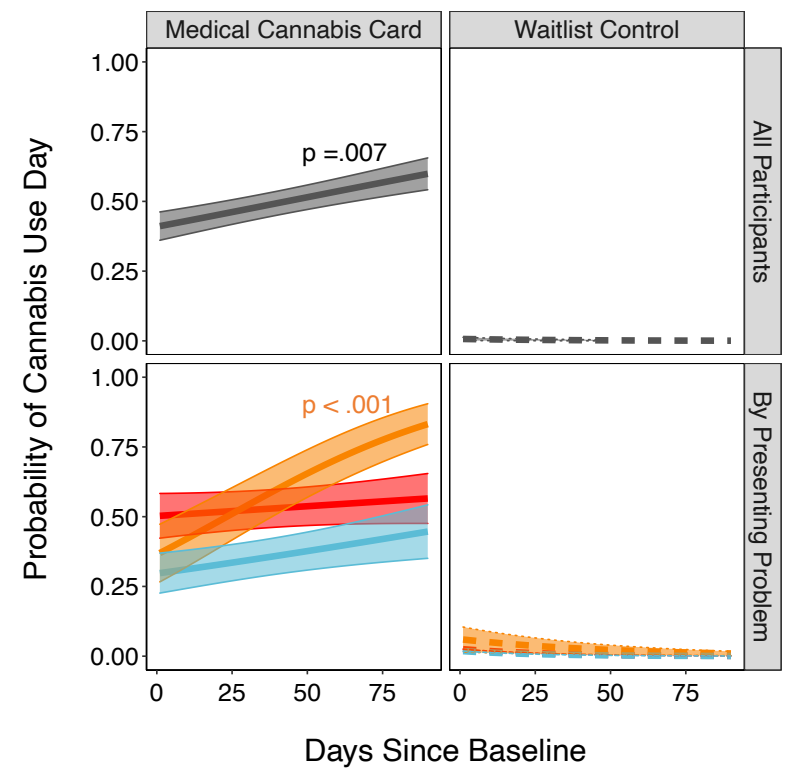

All Participants $\begin{aligned} & \text { Presenting Problem: } \\ & \text { Mood }\end{aligned}$

Figure 4. Duration of Cannabis' Effect on Self-Reported Sleep. A) Sleep quality changes across the 90-day daily diary period for medical cannabis card (MCC, $n=102$; left) and waitlist control (WLC, $n=79$; right) groups shown for all participants in each group (top row) and separately by presenting problem (bottom row). Note, fits and data are averaged across use days and nonuse days. Data points are crossparticipant means and standard errors of raw data; model fit lines are adjusted for random effects and primary model covariates (per-participant age, years of education, and proportion of daily diary days that included cannabis use; see Methods for more detail on parameterization). B) Probability of a cannabis use day across the 90-day daily diary period for the MCC (left) and WLC (right) groups for all participants (top row) and by presenting problem (bottom row). 
medRxiv preprint doi: https://doi.org/10.1101/2022.01.19.22269565; this version posted January 22, 2022. The copyright holder for this preprint (which was not certified by peer review) is the author/funder, who has granted medRxiv a license to display the preprint in perpetuity.

All rights reserved. No reuse allowed without permission.

\section{Discussion}

This project establishes the feasibility and validity of a daily diary, experience sampling design for assessing medical cannabis use. With this method, the project demonstrates that cannabis use is associated with same day improvements in self-reported sleep quality, but not depressive, or pain symptoms. Through the parent project's structure as a pragmatic randomized trial of medical cannabis cards and concurrent use of objective, urinalysis measures of cannabis use, this work also provides convergent evidence to mitigate key potential confounding interindividual difference variables (e.g., variables equivalent across randomization groups: age, education, sex) and reporting bias, respectively, that may have otherwise accounted for the observed associations between same day cannabis use and sleep quality. Nevertheless, the improvement of sleep quality in those assigned to MCC occurred in the context of increasing frequency of cannabis use, suggesting those using cannabis to address problems with sleep should use caution, as more frequent cannabis use is not without risk and could lead to cannabis use disorder (Gilman et al., invited to resubmit, (Gilman et al., 2021a)).

Feasibility and Validity of Daily Diary Design in Medical Cannabis Studies. Completion rates of daily surveys were high across our long-term (90 days) daily diary design (80\% of surveys were completed on average) and approximately equivalent to other, far shorter experience sampling studies of cannabis use (e.g., $>1$ month $60-90 \%$ completion rates (Goodhines et al., 2019)(Verdoux et al., 2003)(Buckner et al., 2012). Using per-participant and group-level analysis procedures, we also found that completion rates remained within this range throughout the study period (Supplemental S3). We did find small, but significant associations suggesting older participants and those with higher education had higher daily survey completion rates. Given the novelty of the current study design for those seeking medical cannabis however, 
medRxiv preprint doi: https://doi.org/10.1101/2022.01.19.22269565; this version posted January 22, 2022. The copyright holder for this preprint (which was not certified by peer review) is the author/funder, who has granted medRxiv a license to display the preprint in perpetuity.

All rights reserved. No reuse allowed without permission.

future work should seek replication of these associations. The small magnitude of the associations between completion rates and demographic factors and high overall completion rate in this study nevertheless suggest broad feasibility of this daily diary design of medical cannabis uses.

The current work also validates the daily diary, experience sampling method for medical cannabis, as cannabis use frequency derived from daily surveys well-aligned with field-standard, interview-based cannabis assessment as well as cannabinoid metabolite detection from urinalysis. To our knowledge, this is the first validation of daily, web-based cannabis use metrics with field standard interview assessments and urinalysis in medical cannabis use. Moreover, even among the rapidly increasing number of experience sampling studies of recreational cannabis use, few studies have sought validation of web-based cannabis assessments. While existing evidence has already suggested general validity of self-reported cannabis frequency (Martin et al., 1988) (although questions remain for cannabis dose and potency (van der Pol et al., 2013)), the current validation of daily web-based cannabis assessments provides essential clarification and support of modern experience sampling studies of cannabis use.

Feasible and valid web-based assessments of medical cannabis use are well-suited to current, highly variable real-world patterns of medical cannabis use that lack federal regulation, physician oversight, and clear guidelines on dosing. Such daily diary assessments of medical cannabis may thus capture both real-world patterns of cannabis use in future pragmatic clinical trials and also compliment formal efficacy trials to monitor study adherence and collect additional day-to-day or moment-to-moment use patterns. Web-based daily diary cannabis assessments will also be useful in future research that integrates photography or video to better 
medRxiv preprint doi: https://doi.org/10.1101/2022.01.19.22269565; this version posted January 22, 2022. The copyright holder for this preprint (which was not certified by peer review) is the author/funder, who has granted medRxiv a license to display the preprint in perpetuity.

All rights reserved. No reuse allowed without permission.

remotely document cannabis product labels and ultimately estimate dosage, in efforts to address current lack of standards in dosage estimates.

\section{Medical Cannabis is Associated with Same Day Improvements in Sleep Symptoms.}

Using the validated daily diary design, we demonstrate that medical cannabis use is associated with an improvement in same night sleep quality. The observed improvement in sleep quality on cannabis use days, compared to nonuse days, was small-to-moderate $(\Delta \mathrm{z} \sim .18)$ with respect to current effect size benchmarks (typical psychology effect sizes ranging between $\mathrm{r}=.11$ and $\mathrm{r}=.29$ (Gignac and Szodorai, 2016)) and is considered to be practically (Funder and Ozer, 2019) and likely clinically (Rutledge and Loh, 2004) meaningful. This is notable as such small-to-moderate improvement is observed on the level of single days, instead of inter-individual differences or long-term change over the course of many weeks in which effect sizes are often interpreted (see (Gabriel et al., 2019)for more discussion). Same day sleep improvements among new medical cannabis users is consistent with prior work in a community sample of college students during a shorter monitoring period (14 days) that demonstrated self-reported same day sleep improvements among recreational cannabis users (Goodhines et al., 2019). These same day, within-person effects of cannabis-related sleep improvements are further consistent with a metaanalysis of sleep outcomes from clinical trials of therapeutic cannabinoids (Abrams, 2018) that found an overall small effect size, with 11 out of 19 trials reporting improvements in sleep quality or sleep disturbances

Supporting clinical research, basic science highlights an essential role of the endogenous cannabinoid system in sleep (see (Prospéro-García et al., 2016)(Babson et al., 2017) for review). Consistent with a potential direct role of cannabis use on sleep, this prior research has particularly implicated the CB1 receptor (Mechoulam et al., 1997)(Prospéro-García et al., 2016), 
medRxiv preprint doi: https://doi.org/10.1101/2022.01.19.22269565; this version posted January 22, 2022. The copyright holder for this preprint (which was not certified by peer review) is the author/funder, who has granted medRxiv a license to display the preprint in perpetuity.

All rights reserved. No reuse allowed without permission.

where the primary psychoactive component of cannabis, $\Delta 9$-tetrahydrocannabinol (THC) is a partial agonist (Pertwee, 2008). In the context of emerging indirect, observational, and openlabel/single-blinded clinical research and established basic science, expanded research investigating cannabinoids as a treatment for sleep challenges is warranted. The success of the current project utilizing an experience sampling, daily diary design suggests such treatment research may optimally utilize flexible, ecologically valid designs together with expanded and more objective sleep assessments within these ecologically valid designs (e.g. actigraphy watches).

\section{Medical Cannabis is not Associated with Same Day Improvements in Pain or Mood}

Symptoms. We did not find same day improvements in pain or depressive symptoms, which is consistent with our prior work looking at 12-week changes in health symptoms from in-person monthly assessments (i.e., non-daily diary) in adults randomized to receive a medical cannabis card (e.g. Gilman et al., invited to resubmit, (Gilman et al., 2021a)). Chronic pain is one of the most common complaints leading to an interest in medical cannabis use (Reinarman et al., 2011) and while some preclinical models suggest cannabinoids may regulate pain (Woodhams et al., 2015), clinical results have been inconclusive (Haroutounian et al., 2021)(National Academies of Sciences and Medicine, 2017)(Mücke et al., 2018). The current project finds no substantial evidence of cannabis improving same day pain symptoms. Given the success of the daily diary method for medical cannabis in the current project and established intraindividual variability in chronic pain symptoms (Mun et al., 2019) (O’Brien et al., 2011), however, if pursued, future work may utilize experience sampling designs to further explore same day associations in refined samples with expanded metrics. 
medRxiv preprint doi: https://doi.org/10.1101/2022.01.19.22269565; this version posted January 22, 2022. The copyright holder for this preprint (which was not certified by peer review) is the author/funder, who has granted medRxiv a license to display the preprint in perpetuity.

All rights reserved. No reuse allowed without permission.

Depressive symptoms are also associated with increased cannabis use in epidemiological samples (Onaemo et al., 2020)(Degenhardt et al., 2003) and are frequently cited as a reason to pursue medical cannabis (Reinarman et al., 2011). The current project however did not find substantive improvement in self-reported depressive symptoms among adults randomly assigned to access to medical cannabis use, which is largely consistent with existing evidence (Abrams, 2018). While there was one very small, but statistically significant difference in use versus nonuse days, this relationship was no longer observed when restricting the sample to those with verified cannabinoid metabolites. The high interest in use of cannabis for depressive symptoms together with the lack of improvement in depression symptoms among those using medical cannabis is concerning given that those with affective disorders (e.g., depression, anxiety disorders) are likely at significantly increased risk for developing a cannabis use disorder (Onaemo et al., 2020) Additional work suggests heavy cannabis use may increase risk for depression (Smolkina et al., 2017)(Lev-Ran et al., 2014) and other psychiatric illnesses (Livne et al., 2022)(although also see (Haney and Evins, 2016)), particularly among adolescents and young adults who often use cannabis in the context of normative, functional brain changes (Luna et al., 2015; Tervo-Clemmens et al., 2020). Taken together, it will be important for future medical cannabis treatment research to carefully assess symptoms of cannabis use disorder during treatment course and evaluate for exacerbation in depressive and other psychiatric symptoms.

Limitations. This project is highlighted by several strengths, including randomization of participants to medical cannabis card access, a novel daily diary, experience sampling design, biochemical and interview-based validation of daily cannabis surveys, and a relatively large sample size for the number of repeated assessments (e.g., 181 participants with a median number 
medRxiv preprint doi: https://doi.org/10.1101/2022.01.19.22269565; this version posted January 22, 2022. The copyright holder for this preprint (which was not certified by peer review) is the author/funder, who has granted medRxiv a license to display the preprint in perpetuity.

All rights reserved. No reuse allowed without permission.

of 72 assessments per-participant). There are, however, limitations worth noting. First, the current project relied on exploratory analyses of daily self-reported single-item assessments of sleep, pain, and mood symptoms that were included in the design to minimize participant burden and maximize completion over the very long study period (90 daily diary days). It is however essential for future work to consider replicating these results with objective measures and validated, clinician-blinded ratings. Another potential limitation of the current project is the likelihood of a high degree of variability of cannabis route of administration, dose, and potency among participants using medical cannabis. In part, the current, pragmatic study of medical cannabis was designed to test for effectiveness given these variable, real-world conditions, where participants are permitted to make their own decisions regarding cannabis products and dosing. While we performed sensitivity analyses to ensure that the results were unchanged when restricting analyses to those with cannabinoid metabolites detected in their urine, lack of daily information on dosing, route of administration, and potency, prevent clear conclusions regarding pharmacological effects of cannabis. The success of the long-term web-based daily cannabis surveys and experience sampling design however, suggests future work with expanded objective measures of cannabis dose and potency (e.g., through regular laboratory-based testing) may be integrated with ecologically valid data collection on day-to-day use patterns and health symptoms.

Conclusion. This project establishes the feasibility and validity of integrating a daily diary design into a pragmatic clinical trial of medical cannabis. Within this design, exploratory analyses support same-day improvements in sleep, but not pain or mood symptoms. Future work with expanded and objective measures of cannabis use and health symptoms, including indices of cannabis use disorder, can build upon the ecologically valid longitudinal design. 
medRxiv preprint doi: https://doi.org/10.1101/2022.01.19.22269565; this version posted January 22, 2022. The copyright holder for this preprint

(which was not certified by peer review) is the author/funder, who has granted medRxiv a license to display the preprint in perpetuity.

All rights reserved. No reuse allowed without permission.

\section{Acknowledgements:}

Conflict of Interest Disclosures: AEE has served as a consultant to Charles River Analytics (NIDA SBIR grant) and Karuna Pharmaceuticals (Chair Data Monitoring Board). BTC has equity holdings in Abbot Laboratories, Gilead Sciences Inc., Medtronic PLC, Pfizer Inc., Thermo Fisher Scientific, Varian Medical Systems Inc., and Waters Corporation. GNP has equity holdings in Pfizer Inc. Other authors report no potential conflicts.

Funding/Support: This work was funded by R01DA042043; PI: JMG.

Role of Funder/Sponsor: The funder had no role in the design and conduct of the study; collection, management, analysis, and interpretation of the data; preparation, review, or approval of the manuscript; and decision to submit the manuscript for publication.

Data Sharing Statement: All data, code, and materials used in the analyses can be provided by Brenden Tervo-Clemmens, Jodi Gilman, and Massachusetts General Hospital pending scientific review and a completed data use agreement/material transfer agreement. Requests for all materials should be submitted to Brenden Tervo-Clemmens and Jodi Gilman. 
medRxiv preprint doi: https://doi.org/10.1101/2022.01.19.22269565; this version posted January 22, 2022. The copyright holder for this preprint (which was not certified by peer review) is the author/funder, who has granted medRxiv a license to display the preprint in perpetuity.

\section{References}

Abrams DI (2018) The therapeutic effects of Cannabis and cannabinoids: An update from the National Academies of Sciences, Engineering and Medicine report. Elsevier European journal of internal medicine 49, 7-11.

Analgesia IPTF on C and C (2021) International Association for the Study of Pain Presidential Task Force on Cannabis and Cannabinoid Analgesia position statement. PAIN 162, S1.

Association AP (2013) Diagnostic and statistical manual of mental disorders (DSM- $\left.{ }^{\circledR}\right)$. American Psychiatric Pub.

Babson KA, Sottile J, Morabito D (2017) Cannabis, cannabinoids, and sleep: a review of the literature. Springer Current psychiatry reports 19, 1-12.

Boehnke KF, Gangopadhyay S, Clauw DJ, Haffajee RL (2019) Qualifying conditions of medical cannabis license holders in the United States. Health Affairs 38, 295-302.

Buckner JD, Crosby RD, Silgado J, Wonderlich SA, Schmidt NB (2012) Immediate antecedents of marijuana use: An analysis from ecological momentary assessment. Elsevier Journal of behavior therapy and experimental psychiatry 43, 647-655.

Budney AJ, Hughes JR, Moore BA, Novy PL (2001) Marijuana abstinence effects in marijuana smokers maintained in their home environment. American Medical Association Archives of general psychiatry 58, 917-924.

Cranford JA, Bohnert KM, Perron BE, Bourque C, Ilgen M (2016) Prevalence and correlates of 'Vaping' as a route of cannabis administration in medical cannabis patients. Elsevier Drug and alcohol dependence 169, 41-47.

Csikszentmihalyi M, Larson $\mathbf{R}$ (2014) Validity and reliability of the experience-sampling method. In Flow and the foundations of positive psychology , pp 35-54 Springer.

Cumming G (2014) The new statistics: Why and how. Sage Publications Sage CA: Los Angeles, CA Psychological science 25, 7-29.

Degenhardt L, Hall W, Lynskey M (2003) Exploring the association between cannabis use and depression. Wiley Online Library Addiction 98, 1493-1504.

Funder DC, Ozer DJ (2019) Evaluating effect size in psychological research: Sense and nonsense. Sage Publications Sage CA: Los Angeles, CA Advances in Methods and Practices in Psychological Science 2, 156-168.

Gabriel AS, Podsakoff NP, Beal DJ, Scott BA, Sonnentag S, Trougakos JP, Butts MM (2019) Experience sampling methods: A discussion of critical trends and considerations for scholarly 
medRxiv preprint doi: https://doi.org/10.1101/2022.01.19.22269565; this version posted January 22, 2022. The copyright holder for this preprint (which was not certified by peer review) is the author/funder, who has granted medRxiv a license to display the preprint in perpetuity.

All rights reserved. No reuse allowed without permission.

advancement. SAGE Publications Sage CA: Los Angeles, CA Organizational Research Methods 22, 969-1006.

Gignac GE, Szodorai ET (2016) Effect size guidelines for individual differences researchers. Elsevier Personality and individual differences 102, 74-78.

Gilman JM, Schmitt WA, Tervo-Clemmens B, Hickey S, Potter K, Schuster RM, cooke megan, Pachas GN, Evins AE (2021a) A Twelve-Week Trial of Medical Marijuana Cards in Adults with Complaint of Pain, Insomnia, Anxiety or Depressive Symptoms: A Randomized, Pragmatic Clinical Trial. paper presented at American College of Neuropsychopharmacology Conference, Peurto Rico, USA.

Gilman JM, Schmitt WA, Wheeler G, Schuster RM, Klawitter J, Sempio C, Evins AE (2021b) Variation in Cannabinoid Metabolites Present in the Urine of Adults Using Medical Cannabis Products in Massachusetts. American Medical Association JAMA Network Open 4, e215490e215490.

Goodhines PA, Gellis LA, Ansell EB, Park A (2019) Cannabis and alcohol use for sleep aid: A daily diary investigation. American Psychological Association Health Psychology 38, 1036.

Goodman S, Wadsworth E, Leos-Toro C, Hammond D, team ICPS (2020) Prevalence and forms of cannabis use in legal vs. illegal recreational cannabis markets. Elsevier International Journal of Drug Policy 76, 102658.

Goodwin RS, Darwin WD, Chiang CN, Shih M, Li S-H, Huestis MA (2008) Urinary elimination of 11-nor-9-carboxy- $\Delta$ 9-tetrahydrocannnabinol in cannabis users during continuously monitored abstinence. Oxford University Press Journal of analytical toxicology 32, 562-569.

Haney M, Evins AE (2016) Does cannabis cause, exacerbate or ameliorate psychiatric disorders? An oversimplified debate discussed. Nature Publishing Group Neuropsychopharmacology 41, 393-401.

Haroutounian S, Arendt-Nielsen L, Belton J, Blyth FM, Degenhardt L, Di Forti M, Eccleston C, Finn DP, Finnerup NB, Fisher E (2021) IASP Presidential Task Force on Cannabis and Cannabinoid Analgesia: research agenda on the use of cannabinoids, cannabis, and cannabisbased medicines for pain management. LWW Pain.

Hazekamp A, Ware MA, Muller-Vahl KR, Abrams D, Grotenhermen F (2013) The medicinal use of cannabis and cannabinoids - an international cross-sectional survey on administration forms. Taylor \& Francis Journal of psychoactive drugs 45, 199-210.

Ji L, Chow S-M, Schermerhorn AC, Jacobson NC, Cummings EM (2018) Handling Missing Data in the Modeling of Intensive Longitudinal Data. Routledge Structural Equation Modeling: A Multidisciplinary Journal 25, 715-736. 
medRxiv preprint doi: https://doi.org/10.1101/2022.01.19.22269565; this version posted January 22, 2022. The copyright holder for this preprint (which was not certified by peer review) is the author/funder, who has granted medRxiv a license to display the preprint in perpetuity. All rights reserved. No reuse allowed without permission.

Kahneman D, Krueger AB, Schkade DA, Schwarz N, Stone AA (2004) A survey method for characterizing daily life experience: The day reconstruction method. American Association for the Advancement of Science Science 306, 1776-1780.

Lev-Ran S, Roerecke M, Le Foll B, George TP, McKenzie K, Rehm J (2014) The association between cannabis use and depression: a systematic review and meta-analysis of longitudinal studies. Cambridge University Press Psychological medicine 44, 797.

Lintzeris N, Driels J, Elias N, Arnold JC, McGregor IS, Allsop DJ (2018) Medicinal cannabis in Australia, 2016: the cannabis as medicine survey (CAMS-16). Wiley Online Library Medical Journal of Australia 209, 211-216.

Livne O, Shmulewitz D, Sarvet AL, Wall MM, Hasin DS (2022) Association of cannabis userelated predictor variables and self-reported psychotic disorders: US adults, 2001-2002 and 2012-2013. Am Psychiatric Assoc American journal of psychiatry 179, 36-45.

Luna B, Marek S, Larsen B, Tervo-Clemmens B, Chahal R (2015) An integrative model of the maturation of cognitive control. Annual Reviews Annual review of neuroscience 38, 151-170.

MacCallum CA, Russo EB (2018) Practical considerations in medical cannabis administration and dosing. Elsevier European journal of internal medicine 49, 12-19.

Martin GW, Wilkinson DA, Kapur BM (1988) Validation of self-reported cannabis use by urine analysis. Addictive Behaviors 13, 147-150.

Mead A (2017) The legal status of cannabis (marijuana) and cannabidiol (CBD) under US law. Elsevier Epilepsy \& Behavior 70, 288-291.

Mechoulam R, Fride E, Hanu L, Sheskin T, Bisogno T, Di Marzo V, Bayewitch M, Vogel Z (1997) Anandamide may mediate sleep induction. Nature Publishing Group Nature 389, 25-26.

Mücke M, Phillips T, Radbruch L, Petzke F, Häuser W (2018) Cannabis-based medicines for chronic neuropathic pain in adults. John Wiley \& Sons, Ltd Cochrane Database of Systematic Reviews.

Mun CJ, Suk HW, Davis MC, Karoly P, Finan P, Tennen H, Jensen MP (2019) Investigating intraindividual pain variability: methods, applications, issues, and directions. LWW Pain 160, 2415-2429.

National Academies of Sciences, Medicine (2017) The health effects of cannabis and cannabinoids: the current state of evidence and recommendations for research. National Academies Press.

O'Brien EM, Waxenberg LB, Atchison JW, Gremillion HA, Staud RM, McCrae CS, Robinson ME (2011) Intraindividual variability in daily sleep and pain ratings among chronic pain patients: 
medRxiv preprint doi: https://doi.org/10.1101/2022.01.19.22269565; this version posted January 22, 2022. The copyright holder for this preprint (which was not certified by peer review) is the author/funder, who has granted medRxiv a license to display the preprint in perpetuity.

All rights reserved. No reuse allowed without permission.

bidirectional association and the role of negative mood. LWW The Clinical journal of pain 27, 425-433.

Onaemo VN, Fawehinmi TO, D’Arcy C (2020) Comorbid Cannabis Use Disorder with Major Depression and Generalized Anxiety Disorder: A Systematic Review and Meta-Analyses of nationally representative epidemiological surveys. Elsevier Journal of affective disorders.

Pacula RL, Boustead AE, Hunt P (2014) Words can be deceiving: a review of variation among legally effective medical marijuana laws in the United States. De Gruyter Journal of drug policy analysis 7, 1-19.

Pertwee RG (2008) The diverse CB1 and CB2 receptor pharmacology of three plant cannabinoids: $\Delta$ 9-tetrahydrocannabinol, cannabidiol and $\Delta 9$-tetrahydrocannabivarin. Wiley Online Library British journal of pharmacology 153, 199-215.

van der Pol P, Liebregts N, de Graaf R, Korf DJ, van den Brink W, van Laar M (2013) Validation of self-reported cannabis dose and potency: an ecological study. Wiley Online Library Addiction 108, 1801-1808.

Prospéro-García O, Amancio-Belmont O, Meléndez ALB, Ruiz-Contreras AE, Méndez-Díaz M (2016) Endocannabinoids and sleep. Elsevier Neuroscience \& Biobehavioral Reviews 71, 671679.

Reinarman C, Nunberg H, Lanthier F, Heddleston T (2011) Who are medical marijuana patients? Population characteristics from nine California assessment clinics. Taylor \& Francis Journal of psychoactive drugs 43, 128-135.

Rutledge T, Loh C (2004) Effect sizes and statistical testing in the determination of clinical significance in behavioral medicine research. Springer Annals of Behavioral Medicine 27, 138145.

Sarris J, Sinclair J, Karamacoska D, Davidson M, Firth J (2020) Medicinal cannabis for psychiatric disorders: a clinically-focused systematic review. BioMed Central BMC psychiatry 20, 1-14.

Schuster RM, Mermelstein RJ, Hedeker D (2016) Ecological momentary assessment of working memory under conditions of simultaneous marijuana and tobacco use. Wiley Online Library Addiction 111, 1466-1476.

Schuster RM, Potter K, Vandrey R, Hareli M, Gilman J, Schoenfeld D, Evins AE (2020) Urinary 11-nor-9-carboxy-tetrahydrocannabinol elimination in adolescent and young adult cannabis users during one month of sustained and biochemically-verified abstinence. SAGE Publications Sage UK: London, England Journal of Psychopharmacology 34, 197-210. 
medRxiv preprint doi: https://doi.org/10.1101/2022.01.19.22269565; this version posted January 22, 2022. The copyright holder for this preprint (which was not certified by peer review) is the author/funder, who has granted medRxiv a license to display the preprint in perpetuity.

All rights reserved. No reuse allowed without permission.

Sexton M, Cuttler C, Finnell JS, Mischley LK (2016) A cross-sectional survey of medical cannabis users: patterns of use and perceived efficacy. Mary Ann Liebert, Inc. 140 Huguenot Street, 3rd Floor New Rochelle, NY 10801 USA Cannabis and cannabinoid research 1, 131-138.

Smolkina M, Morley KI, Rijsdijk F, Agrawal A, Bergin JE, Nelson EC, Statham D, Martin NG, Lynskey MT (2017) Cannabis and depression: a twin model approach to co-morbidity. Springer Behavior genetics 47, 394-404.

Snaith RP (2003) The hospital anxiety and depression scale. BioMed Central Health and quality of life outcomes 1, 1-4.

Soldatos CR, Dikeos DG, Paparrigopoulos TJ (2000) Athens Insomnia Scale: validation of an instrument based on ICD-10 criteria. Elsevier Journal of psychosomatic research 48, 555-560.

Tan G, Jensen MP, Thornby JI, Shanti BF (2004) Validation of the Brief Pain Inventory for chronic nonmalignant pain. Elsevier The Journal of Pain 5, 133-137.

Tervo-Clemmens B, Quach A, Calabro FJ, Foran W, Luna B (2020) Meta-analysis and review of functional neuroimaging differences underlying adolescent vulnerability to substance use.

Elsevier Neurolmage 209, 116476.

Vandrey R, Raber JC, Raber ME, Douglass B, Miller C, Bonn-Miller MO (2015) Cannabinoid dose and label accuracy in edible medical cannabis products. American Medical Association Jama 313, 2491-2493.

Verdoux H, Gindre C, Sorbara F, Tournier M, D SWENDSEN J (2003) Effects of cannabis and psychosis vulnerability in daily life: an experience sampling test study. Cambridge University Press Psychological medicine 33, 23.

Woodhams SG, Sagar DR, Burston JJ, Chapman V (2015) The role of the endocannabinoid system in pain. Springer Pain control 119-143. 
medRxiv preprint doi: https://doi.org/10.1101/2022.01.19.22269565; this version posted January 22, 2022. The copyright holder for this preprint (which was not certified by peer review) is the author/funder, who has granted medRxiv a license to display the preprint in perpetuity.

All rights reserved. No reuse allowed without permission.

Supplemental S1. Cannabinoid Quantification from Urinalysis.

The quantification and detection of cannabinoid metabolites from urinalysis for this sample has been previously presented (Gilman et al., 2021b). We used identical scoring procedures as detailed in this prior work. Owing to the high degree of individual variability in metabolite detection from urinalysis that is dependent on person-specific (e.g., route of administration, hydration, metabolism and excretion rates) and methodological (e.g., assay sensitivity, specificity, and accuracy) factors (Goodwin et al., 2008), we used the composite metrics from (Gilman et al., 2021b) that coded whether urine samples contained any cannabinoid metabolites or any THC metabolites. Samples were tested for the following THC metabolites: 11-hydroxy- $\Delta$ 9-tetrahydrocannabinol, 1-nor- $\Delta$ 9-tetrahydrocannabinol-9-carboxylic acid glucuronide, 11-Nor-9-carboxy- $\Delta$ 9-tetrahydrocannabinol, 11-nor-9-carboxy- $\Delta$ 9tetrahydrocannabivarin, $\Delta 9$-tetrahydrocannabinol glucuronide, $\Delta 9$-tetrahydrocannabivarin, as well as the following additional cannabinoid metabolites: 6-alpha-hydroxy-cannabidiol; 6-betahydroxy-cannabidiol; 7-hydroxy-cannabidiol; (3R-trans)-cannabidiol-7-oic acid;

cannabichromene; cannabidiol; cannabidiol glucuronide; cannabidivarin; cannabigerol; cannabinol. 
Supplemental S2. Sensitivity Analyses Restricting MCC group to those with Cannabinoid Metabolites Detected in their Urine During the Daily Diary Period.

A.

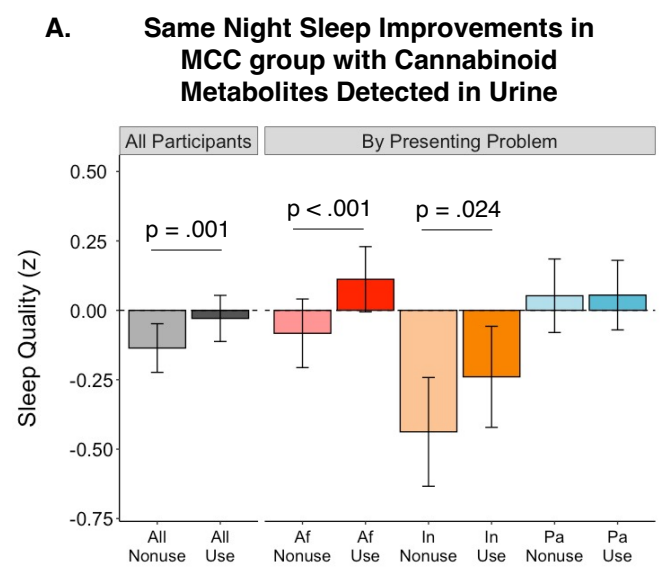

C. Same Day Depression Symptoms in MCC group with Cannabinoid Metabolites Detected in Urine

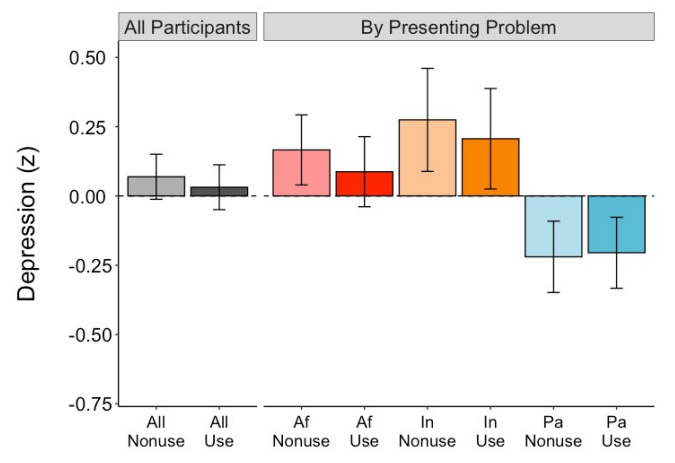

B. Long-Term Sleep Changes Following Randomization in MCC group with Cannabinoid Metabolites Detected in Urine

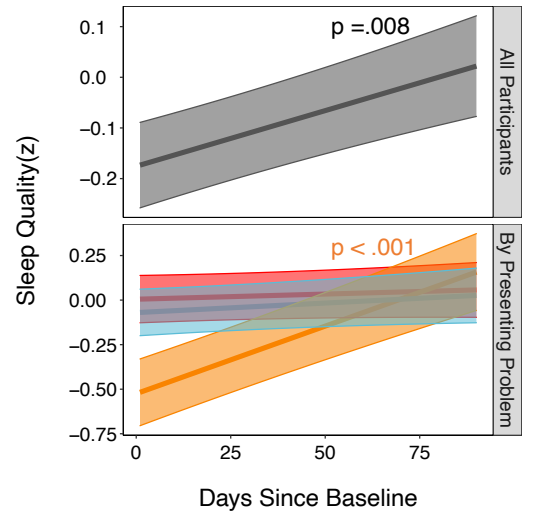
$\begin{array}{ll}\text { Pll Participants } & \begin{array}{l}\text { Presenting Problem: } \\ \text { Mood Sleep Pain }\end{array}\end{array}$

Figure S2. A) Differences in self-reported same night sleep quality (A in cannabis use days (darker colors) and nonuse days (lighter colors) in the medical cannabis card (MCC) group with cannabinoid metabolites detected in their urine ( $\mathrm{N}=86$; See main manuscript and $\mathrm{S} 2$ for more discussion). Values shown for all MCC participants (left) and those whose presenting problem was mood (depression or anxiety symptoms, Af: red), challenges with sleep (In: orange), or pain (Pa:blue). Displayed values are estimated marginal means and their standard errors from linear mixed effects models fit in primary analyses (covariates included the proportion of daily diary days that included cannabis use [i.e., betweenperson effect]; to improve model stability in this smaller sample and owing to the lack of predictive utility from participant age and years of education in primary models (p's $>.473$ ), these covariates were removed from the models in these supplementary analysis. Inference regarding statistical significance was not changed with or without their inclusion. Models were otherwise identical to primary analysis: see Methods for more detail on parameterization. B) Sleep quality changes across the 90-day daily diary period for the MCC group with cannabinoid metabolites detected in their urine $(\mathrm{N}=86)$ shown for all participants (top row) and separately by presenting problem (bottom row). Note, fits are averaged across use days and nonuse days. C) Differences in self-reported same day depression symptoms in the medical cannabis card (MCC) group with cannabinoid metabolites detected in their urine $(\mathrm{N}=86)$ shown for all participants (left) and separately by presenting problem (right) as in (A). 
medRxiv preprint doi: https://doi.org/10.1101/2022.01.19.22269565; this version posted January 22, 2022. The copyright holder for this preprint (which was not certified by peer review) is the author/funder, who has granted medRxiv a license to display the preprint in perpetuity.

All rights reserved. No reuse allowed without permission.

Supplemental S3. Visualization of Completed Daily Diaries Across the Study Period.

A. Daily Diary Completion in
Medical Cannabis Card Group

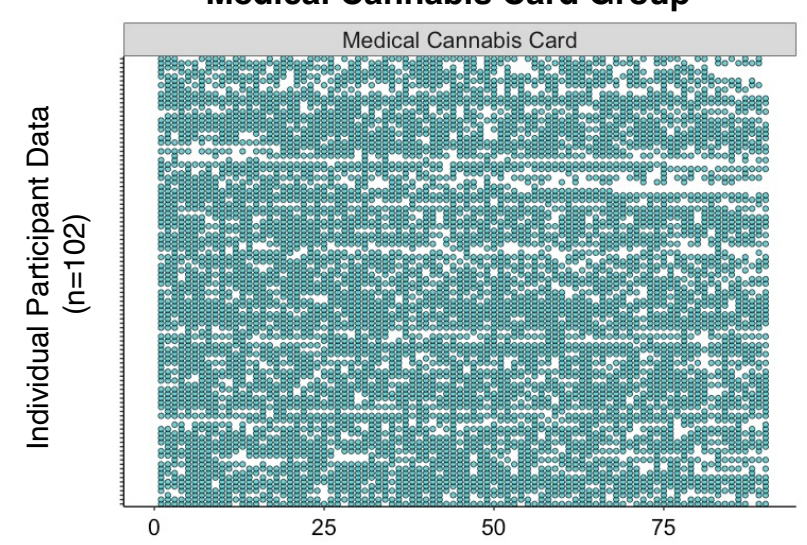

Days Since Baseline

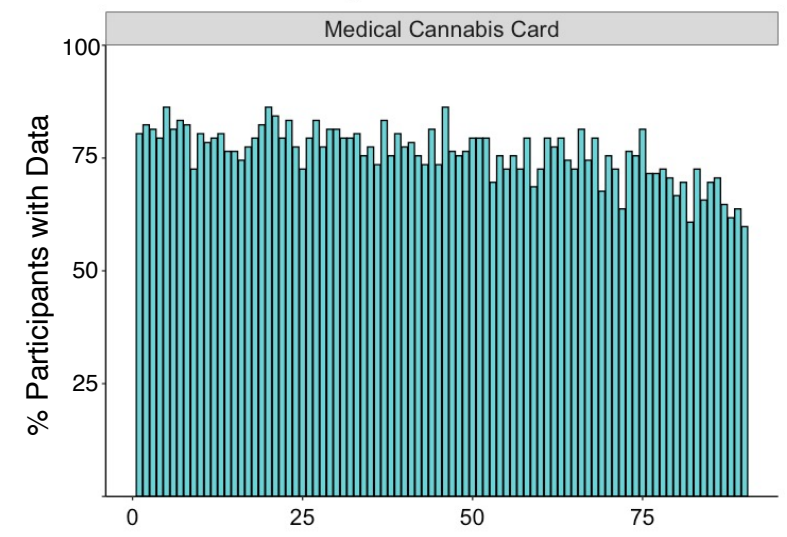

Days Since Baseline
B. Daily Diary Completion in
Waitlist Control Group

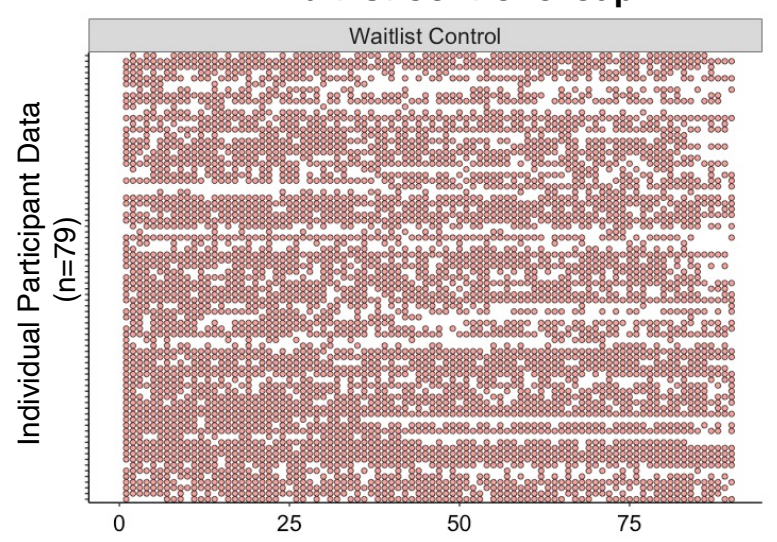

Days Since Baseline

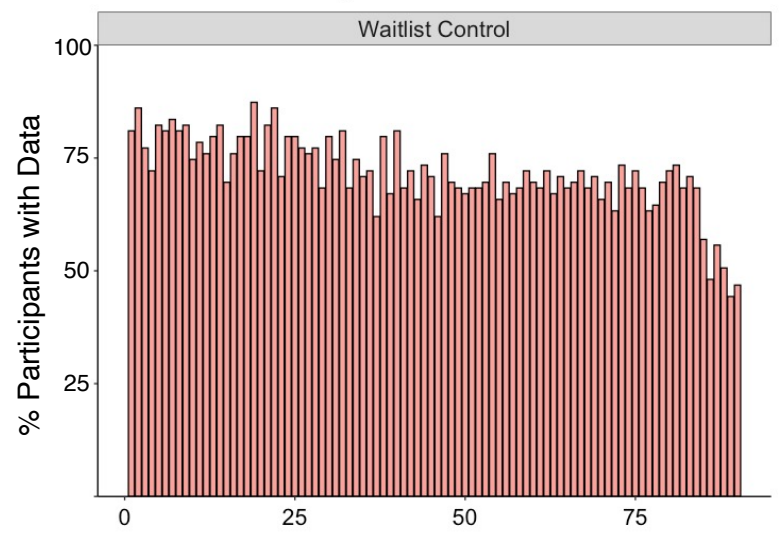

Days Since Baseline

Figure S3. A) Medical Cannabis Card group $(n=102)$ daily diary completion. Top: visualization of perparticipant daily diary completion, where each row corresponds to one participant across all 90 days of the study period; filled circles represent completed daily survey; open circles represent noncompleted/missing survey. Bottom: percent of participants with completed surveys for each of the 90 study days. B) Waitlist Control group $(\mathrm{n}=79)$ daily diary completion. Top: as in $\mathbf{A}$, per-participant daily diary completion. Bottom: As in A, percent of participants with completed surveys for each of the 90 study days. 